\title{
Geothermal Monitoring of Kueishantao Island Offshore of Northeastern Taiwan
}

\author{
Hsieh Tang Chiang, ${ }^{1, *}$, Chuen-Tien Shyu ${ }^{1}$, Hong-I Chang ${ }^{1}$, Shuhjong Tsao ${ }^{2}$, and Chi-Xuan Chen ${ }^{2}$ \\ ${ }^{1}$ Institute of Oceanography, National Taiwan University, Taipei, Taiwan, ROC \\ ${ }^{2}$ Central Geological Survey, Ministry of Economic Affairs, Taipei, Taiwan, ROC
}

Received 12 December 2008, accepted 2 November 2009

\begin{abstract}
To understand the geothermal variation of the active volcano, Kueishantao island, we conducted continuous monitoring of borehole temperatures beginning in July 2006. Fifteen miniature temperature loggers with resolution better than $0.001^{\circ} \mathrm{C}$ were deployed at different depths in a $290-\mathrm{m}$ well. The borehole temperatures ranged between 22 and $34^{\circ} \mathrm{C}$. No significant annual variation was found below $30 \mathrm{~m}$ depth. We divided the geotherm into three sections. The shallow one, at a depth less than $110 \mathrm{~m}$, showed an extreme negative geothermal gradient of $-0.6^{\circ} \mathrm{C}(100 \mathrm{~m})^{-1}$, which may be strongly affected by the convection of shallow water. The middle section, at a depth between 110 and $250 \mathrm{~m}$, had a geotherm of $9.7^{\circ} \mathrm{C}(100 \mathrm{~m})^{-1}$. The heat flow was estimated to be $153 \mathrm{~mW} \mathrm{~m}^{-2}$, on the same order as that acquired on the seafloor around Kueishantao island. The lower portion, below $250 \mathrm{~m}$ depth, showed a geotherm of $-8.5^{\circ} \mathrm{C}(100 \mathrm{~m})^{-1}$ which may be effected by a fracture zone identified by the drilling data. The average geotherm for the whole hole is $4.8^{\circ} \mathrm{C}(100 \mathrm{~m})^{-1}$. Several thermal events with amplitudes of $-0.023 \sim 0.015^{\circ} \mathrm{C}$ and durations of tens of hours were found in different depths in the well. These events have been identified to correlate with the occurrences of typhoons. During the study period there were 17 earthquakes greater than 3.4 in magnitude and within $50 \mathrm{~km}$ radius of Kueishantao. However, we did not find any significant relationships between earthquake occurrence and temperature variations in the borehole. More observation data are needed to discuss the mechanism of temperature variation.
\end{abstract}

Key words: Borehole, Kueishantao, Geothermal monitoring, Heat flow, Taiwan

Citation: Chiang, H. T., C. T. Shyu, H. I. Chang, S. Tsao, and C. X. Chen, 2010: Geothermal monitoring of Kueishantao island offshore of northeastern Taiwan. Terr. Atmos. Ocean. Sci., 21, 563-573, doi: 10.3319/TAO.2009.11.02.01(TH)

\section{INTRODUCTION}

The Kueishantao island is located $10 \mathrm{~km}$ offshore northeastern Taiwan and is an active volcano at the southernmost part of Okinawa Trough (Fig. 1). The trough is a back arc spreading basin due to the Philippine Sea plate being subducted northwestward into the Eurasian plate (Lee et al. 1980; Letouzey and Kimura 1986; Sibuet et al. 1998). This island is mainly composed of andesitic lava flow and pyroclastic deposits (Hsu 1963; Chen 1990). Juang and Chen (1989) dated the andesitic rocks using the K-Ar method and derived ages of tens of thousands, to two hundred thousand years. In addition, Chen et al. (2001) dated siltstone xenoliths and proposed that at least four volcano eruptions occurred in the past 7000 years.

\footnotetext{
* Corresponding author

E-mail:d92241007@ntu.edu.tw
}

Several studies have shown that active seismic events have occurred south of the Okinawa Trough. Lin et al. (2007) reported that some submarine volcanoes are still active at the southwestern end of the Okinawa Trough due to the strong low-frequency earthquakes observed beneath the submarine volcanic cones and seamounts. Lin et al. (2004) analyzed the $V p / V s$ distribution extracted from seismic tomography results of NE Taiwan and suggested the existence of a sausage-like cylindrical conduit, related to a magma chamber beneath Kueishantao area. Lou (2001) attributed the high magnetic anomaly offshore NE Taiwan to the extrusive or intrusive volcanoes located there. Yang et al. (2005) reported a high ratio of $\mathrm{He}^{3} / \mathrm{He}^{4}$ in the bubble gas from the sea surface and from submarine vents east of Kueishantao which implied the bubble gases escaped from the mantle with little contamination of shallow crust 


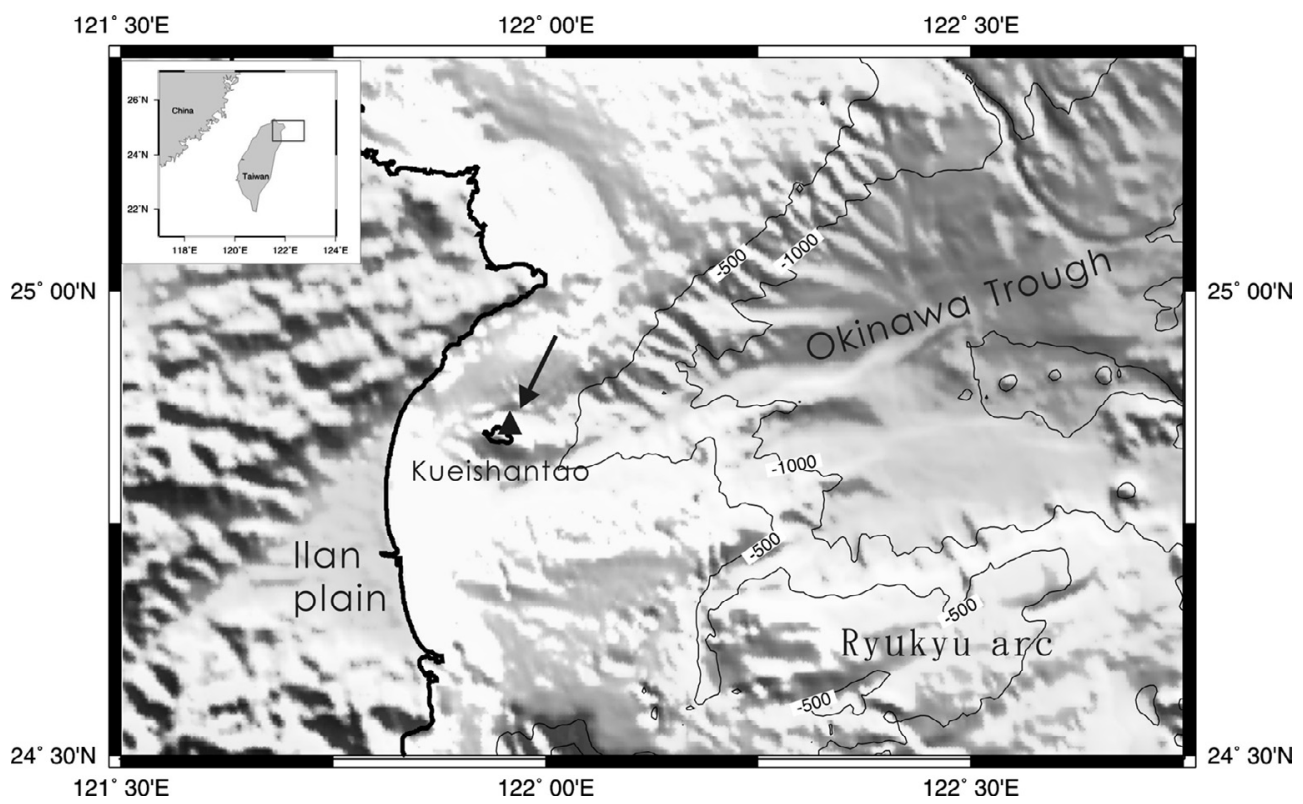

Fig. 1. Locations of Kueishantao geothermal monitoring borehole (arrow).

material. Chen et al. (2005) described a cluster of shallow (<30 m depth) hydrothermal vents for the acidic hydrothermal system offshore NE Taiwan and proposed that shallow magma has caused the spouting of hydrothermal fluid. So far, all geophysical and geochemical data have indicated the fundamental characteristics of volcanic activity in Kueishantao; however, observations of volcanic activity have not been reported.

Temperature monitoring is one method for detecting volcano activity underground (Tilling 1989). Measuring geothermal gradients through time is a fundamental monitoring tool in research on active volcanoes (Zeni et al. 2007). Near the volcano, heat can be transferred by conduction through rock or convection/advection by the movement of fluid (Keller et al. 1979; Hardee 1982; Hurst et al. 1991; Sudo and Hurst 1998). However, to compare the temperature changes with volcanic activity, a single temperature measured at a certain time or certain depth around the volcano is inadequate. Long term monitoring of temperature is needed. Sudo and Hurst (1998) proposed that the changes in temperature associated with volcanic activity could be recognized by continuously measuring temperatures in the borehole. Igarashi et al. (2000) reported long term temperature monitoring for 3.5 months in a borehole in the caldera of the Izu Oshima volcano. They found that borehole temperature variation could be a function of fumarolic gas flux which is expected to be related to volcanic activity.

The resolution of temperature sensors for monitoring should be better than $0.001^{\circ} \mathrm{C}$ in order to capture small temperature perturbations. Also, it is important to record the temperature perturbations at different depths (Chiang et al. 2008a). To establish background knowledge of temperature variations in the subsurface in Kueishantao, two phases of a four-year plan for geothermal monitoring have been conducted by the Central Geological Survey starting in 2004. We used high resolution temperature loggers installed at different depths in a $290-\mathrm{m}$ borehole to measure the temperature variation of Kueishantao. This paper reports the results from our measurements of geotherm, heat flow and temperature in the borehole. We report, for the first time, data regarding geothermal characteristics of an active volcano in Taiwan.

\section{METHODS}

\subsection{Observation Well}

A 400-m observation well was originally planned to be drilled at an elevation of $130 \mathrm{~m}$ east of Kueishantao in February 2006. However, the final drilling depth was only $290 \mathrm{~m}$ due to a serious leakage of mud while drilling from 270 to $290 \mathrm{~m}$. The location of the well is east of the islet near the hot spring and thermal vents founded offshore (Chen et al. 2005). To prevent the borehole wall from collapsing, two coaxial stainless steel casings were installed vertically in the well. The outside 6" casing was set from the ground surface to $80 \mathrm{~m}$ deep, while the inner 4" casing was set from ground to the bottom. The lower $10 \mathrm{~m}$ portion in the bottom was sealed with cement to prevent acid water from flowing into the well. A shelter was constructed to protect the instrumentation. During the installation, more than $95 \%$ of the coring rocks were recovered. The rocks in the borehole were mainly composed of lahar, breccias, fresh 
or hydrothermal lava (Fig. 2). A fracture zone was found in the bottom of the well where the core recovery rate was low and serious mud leakage occurred during drilling.

\subsection{Monitoring Equipment}

We used a string of miniature temperature loggers to monitor borehole temperatures. These types of loggers have been used successfully to measure the heat flow offshore Taiwan (Shyu and Liou 2001). Each logger was $24 \mathrm{~cm}$ in length (including a temperature sensor tube of $2 \mathrm{~cm}$ in length and $0.5 \mathrm{~cm}$ in diameter), $2.2 \mathrm{~cm}$ in diameter, and is protected by a cylindrical container made of titanium with a thickness of $1 \mathrm{~mm}$. One platinum thermistor is inserted into the sensor tube. The measuring and recording electronics are assembled on a chip board which is inserted into the container. All operation power needed is supplied by a replaceable $3.5-\mathrm{V}$ battery. The ambient temperature is sensed by the platinum thermistor and the data are stored on a 1 Megabyte flash RAM. The probe and the container are divided by insulating material. The voltage difference between the probe and the container allows the data to be downloaded to a portable computer without opening the cover.

For the offset corrections of the data loggers, we calibrated the loggers with a CTD at different water depths (2500 - 3500 mbsl) where temperatures are quite stable. The temperature variation of sea water is normally less than $0.001^{\circ} \mathrm{C}$ in 10 minutes.

\subsection{Installation and Data Acquisition}

Fifteen calibrated loggers were installed at depth intervals of $10-30 \mathrm{~m}$ in the $290-\mathrm{m}$ hole after three months of drilling (Fig. 2). The distance between any two loggers was long enough to reduce the temperature deviation caused by air convection in the hole. To prevent sulfate corrosion, all loggers were tied on a titanium wire. We also installed one logger to record temperature at the ground surface.

The 1 Megabyte memory in the logger can store hundreds of days data at the sampling rate of $3 \mathrm{~min}$. and the 3.5-V battery can last for more than 3 years; however, we downloaded the data every two months. Our experience had shown that removing the set of loggers during data download affects the borehole temperature for approximately 40 hours following the disturbance of retrieving the loggers.

\subsection{Thermal Conductivity}

The conductivity of core samples was analyzed by using an ISOMET model 2104 heat transfer analyzer, produced by Applied Precision Ltd. Four core samples from depths of 54, 136, 199, and $270 \mathrm{~m}$ were measured for the thermal conductivity, heat capacity and thermal diffusivity. They were composed of lahar, lahar, lava, and lava with hydrothermal fracture, respectively. To fit the gauge of the analyzer, we cut the core into a short cylinder $6 \mathrm{~cm}$ in diameter and $3 \mathrm{~cm}$ in height. All samples were immersed in water for 3 days before measurement.

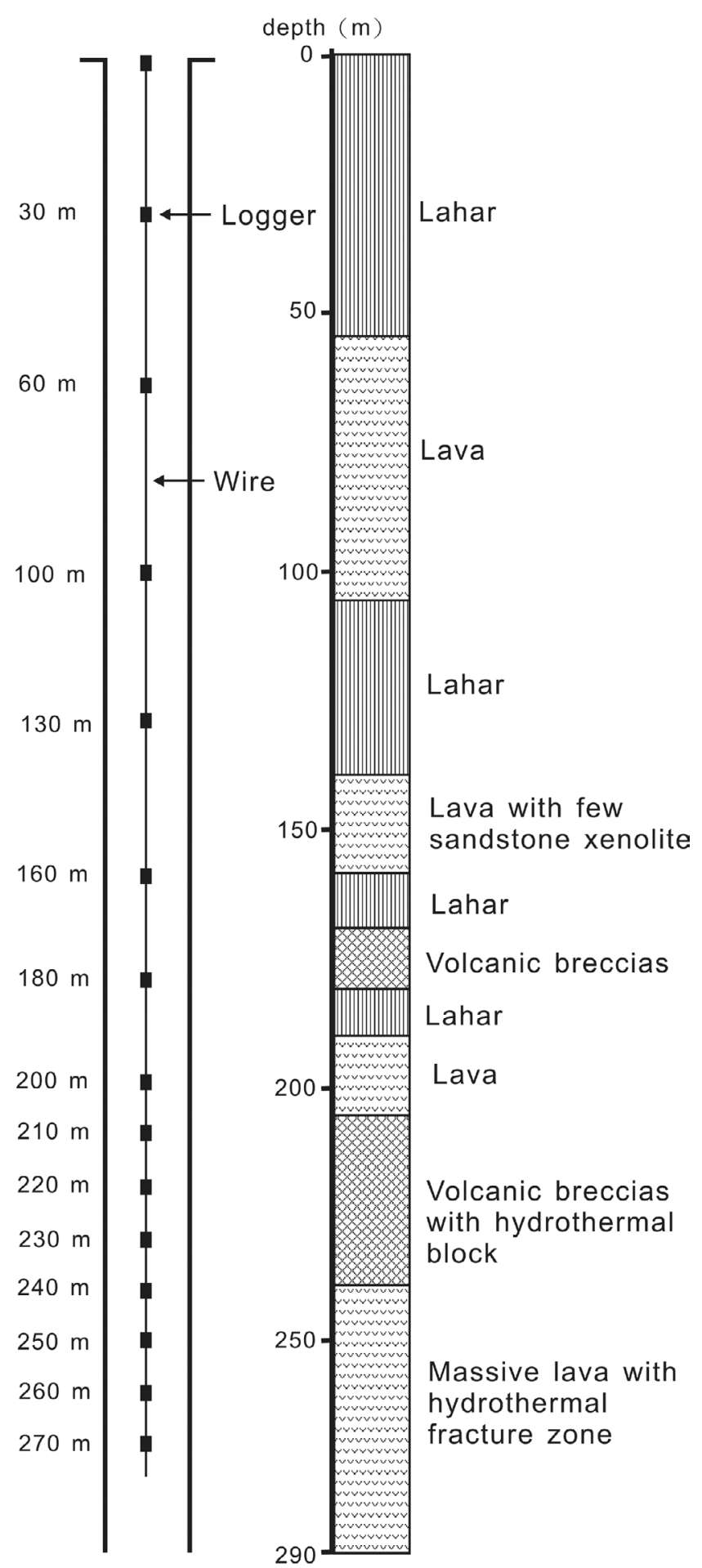

Fig. 2. The geological well section (right) and schematic of temperature loggers (left). The rocks are mainly composed of lahar, breccias, fresh or hydrothermal lava. Fifteen loggers were installed between 0 and $270 \mathrm{~m}$ (CGS 2007). 


\subsection{Geotherm and Heat Flow}

Figure 3 shows the geotherm and the thermal conductivity of the monitoring well. The geotherm was measured with a single thermistor every $10 \mathrm{~m}$ before launching long term monitoring. Except for the shallowest section from 0 to $20 \mathrm{~m}$ below the surface, which is influenced by the short term variation of atmospheric temperature, three geotherm sections can be identified. The upper section is from 20 to $110 \mathrm{~m}$ in depth where the temperature is between 22 and $23^{\circ} \mathrm{C}$. This section showed a negative geotherm of $-0.6^{\circ} \mathrm{C}(100 \mathrm{~m})^{-1}$. The geotherm of this shallow formation could be low due to the effect of groundwater convection (Sudo and Hurst 1998).

Dozens of water wells have revealed a significantly low geotherm caused by groundwater convection in the Ilan plain of northeastern Taiwan (Chiang et al. 2008b). It seems probable that the effect of groundwater convection is the main factor in forming a low geotherm in Kueishantao. We found a rock boundary of lava and lahar at a depth of $110 \mathrm{~m}$. If the upper lava rocks are porous, and the lower lahar rocks are less permeable, a difference in geotherm will be evident. Porous rock can more easily induce the convection of groundwater than can tight rock due to the high permeability. In that event, the low geotherm will also be affected by the lava rock. Global warming could also affect the temperature of the borehole (Harris and Chapman 1997).

In the middle section, from 110 to $250 \mathrm{~m}$, temperatures ranged between 23 and $34^{\circ} \mathrm{C}$ and the geotherm was $9.8^{\circ} \mathrm{C}(100 \mathrm{~m})^{-1}$. The $135 \mathrm{~mW} \mathrm{~m}^{-2}$ heat flow was estimated from the multiplication of geotherm and conductivity values for rock. This heat flow value is close to that found offshore southern Kueishantao where a high geotherm and high heat flow (150 $\mathrm{mW} \mathrm{m}^{-2}$ ) was reported (Chiang et al. 2008a). We infer that a high geotherm and a high heat flow may be common in Kueishantao.

The lower section, below $250 \mathrm{~m}$ depth, showed a sharp negative geotherm of $-8.5^{\circ} \mathrm{C}(100 \mathrm{~m})^{-1}$. It is unusual to find a negative geotherm interspersed with positive geotherms at such deep depth. The negative geotherm indicated that significant heat was removed near the bottom of the hole. Core descriptions revealed a fracture zone at the bottom of the well. A high permeability fracture may have acted as a conduit for cold water movement and reduced the temperature at the bottom.

\subsection{Frequency Analysis}

To understand the periodic variation, we analyzed the frequencies of the temperature variation at each depth. According to our temperature monitoring experience at Tatun volcano located in northern Taiwan (Chiang et al. 2005), a significant daily and annual period was found at very shallow depths ( 1 and $13 \mathrm{~m}$ ) which could be correlated to the at-

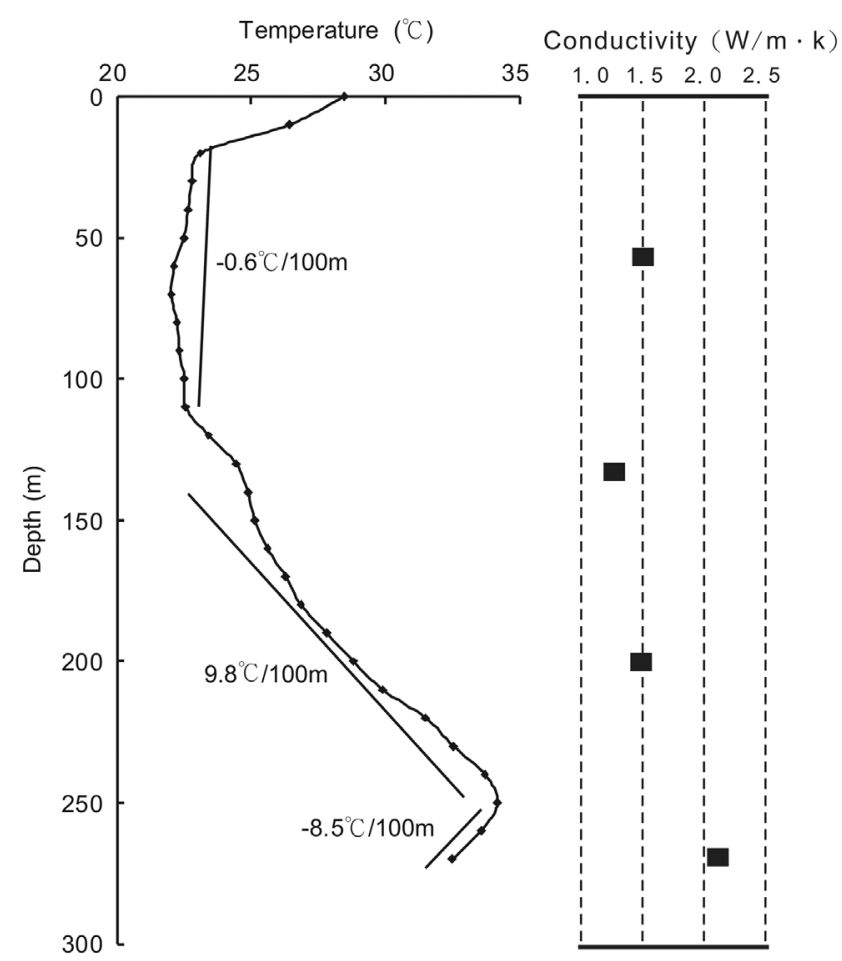

Fig. 3. Temperature profile (left) and thermal conductivity (right) of the core recovered from the monitoring well. Three geotherms, 20 $110,110-250$, and $250-270 \mathrm{~m}$ were identified.

mospheric temperature change. We also found a temporary period of about 4 to 7 days with influence down to $110 \mathrm{~m}$. The period was strongly correlated to the cycle of local rainfall. However, we did not find any evidence for short-term or annual periodicity for borehole temperature variation at Kueishantao site.

\section{RESULTS AND DISCUSSION}

\subsection{Subsurface Temperature and Conductivity of Rock Samples}

The subsurface temperatures ranged between $22-34^{\circ} \mathrm{C}$ between 30 and $270 \mathrm{~m}$ in depth. The temperature variation over two years was small (Fig. 4). Figure 5 shows the individual temperature variations at 15 different depths during the study period. We found that most of the temperatures declined slightly during the period with a rate of about $0.048-0.116^{\circ}{\mathrm{C} \mathrm{yr}^{-1}}^{-}$. Because there were some significant fluctuations during the two year period, we suggest that the general temperature decline during the two years was not caused solely by a drilling effect. In the first two months of monitoring, the decline rates were up to $1.81^{\circ} \mathrm{C} \mathrm{yr}^{-1}$ which was obviously affected by the drilling. Therefore, our observations suggest that these elevated decline rates generated by the drilling effect only happened at the beginning $3-6$ months. 
The measured thermal conductivities are 1.50, 1.29, 1.46, and $2.16 \mathrm{~W}\left(\mathrm{~m} \mathrm{~K}^{-1}\right.$, respectively. These values were unrelated to rock properties; however, the thermal conductivity increased slightly with increasing depth except for the sample at depth $54 \mathrm{~m}$. The heat capacities were in the range of $1.79-1.99 \times 10^{6} \mathrm{~J}(\mathrm{~kg} \mathrm{~K})^{-1}$ and the thermal diffusivities were between $0.72 \times 10^{6}$ and $1.09 \times 10^{6} \mathrm{~m}^{2} \mathrm{~s}^{-1}$ (Table 1).

\subsection{Temperature Variation}

The thermal gradient in boreholes can be influenced by periodic surface temperature fluctuations (STF) or rainfall (Huang et al. 2008; Wu and Zhang 2008). Theoretically, the longer period of STF, the deeper it can have an influence (Carslaw and Jaeger 1959). It is important to ensure that temperature measurements in the borehole are made deep enough so that the STF can be ignored. The effect of STF is dependent on the amplitude of fluctuations, the thermal diffusivity of rock, and the depth. Carslaw and Jaeger (1959; p. 64) suggested a heat conduction equation on half space to predict the quantity of the effect:

$T_{\theta}=T_{0} \times \exp (-\varepsilon z) \sin (\omega t-\varepsilon z)$

where

$T_{\theta}$ : mean value of temperature at a certain depth and time

$T_{0}$ : amplitude of surface temperature change

$\varepsilon$ : parameter of the rock thermal property $\left[\varepsilon=(\pi / P \kappa)^{1 / 2}\right]$

$P:$ the period of seasonal variation

$\kappa:$ thermal diffusivity

$z$ : depth

$\omega:$ frequency

$t$ : time
Using this approach, we estimated that the annual temperature variation on the surface contributed to about $0.01 \%$ of the perturbation at a $30 \mathrm{~m}$ depth given the thermal diffusivity $\left(1 \times 10^{-6} \mathrm{~m} \mathrm{~s}^{-2}\right)$ of the rock. In other words, the perturbation was less than $0.001^{\circ} \mathrm{C}$ if the annual variation on surface is $20^{\circ} \mathrm{C}$. We considered this effect is so small that the seasonal effect can be ignored below $30 \mathrm{~m}$ depth.

The vertical monthly temperatures are shown in Fig. 6. Except for the surface temperature, all temperature variations at each depth were less than $0.215^{\circ} \mathrm{C}$. A subtle temperature variation of $0.084^{\circ} \mathrm{C}$ occurred at a depth of $30 \mathrm{~m}$, possibly related to the seasonal variation on the surface. The maximum annual temperature variation was at the 240 - $270 \mathrm{~m}$ depth. Our results suggest that the temperature may change more easily near the bottom hole fracture zone due to the movement of groundwater.

\subsection{Heat Pulse}

Figure 7 shows five significant heat pulses and rainfall observed during the monitoring period. The heat pulse occurrence dates were exactly the same days typhoons made landfall in Taiwan (Table 2). The apparent influence of typhoons on heat pulses should be more thoroughly examined in future studies. For example, typhoon Fung-Wong was a moderate typhoon. All others were strong typhoons with high wind velocities up to $53 \mathrm{~m} \mathrm{~s}^{-1}$. The amplitudes of heat pulses were not correlated with wind velocities. Heat pulses are positive at 100,130,150,180, and $240 \mathrm{~m}$ depths and are negative at 30,60, 210, 220, and $230 \mathrm{~m}$ depths. However, no signal of heat pulse has been found below $240 \mathrm{~m}$. Groundwater levels may be affected by rainfall or earthquakes (Lin et al. 2008). The positive/negative pulses in duration of 15 to 32 hours may be caused by the change in groundwater level due to the increase in rainfall. Because

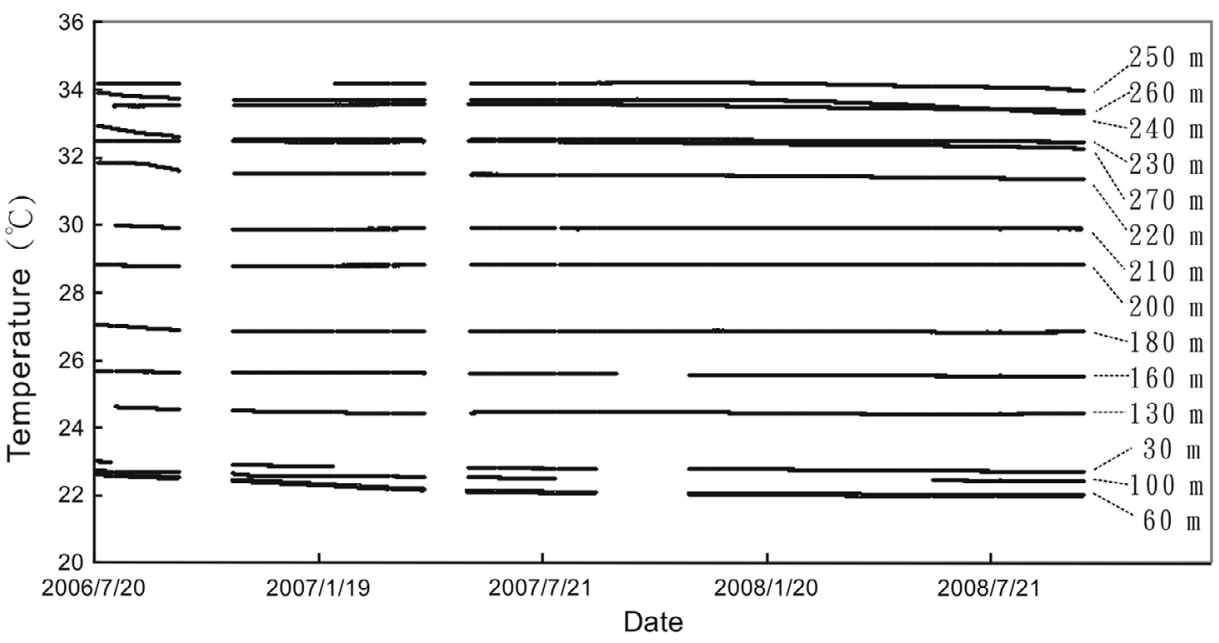

Fig. 4. Daily temperature variation at different depths of the borehole during the period from 2006 to 2008 . 

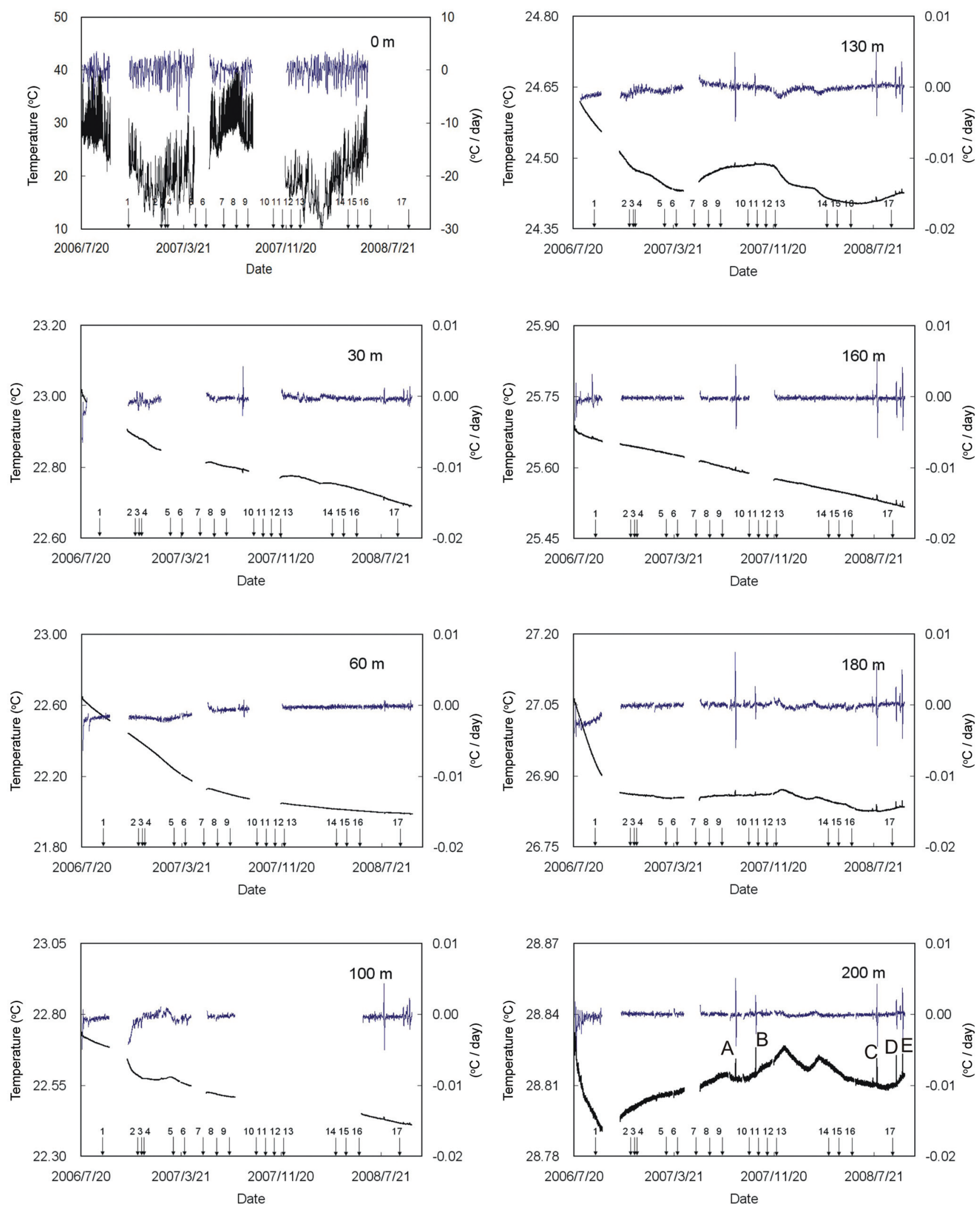

Fig. 5. Temperature variations (lower) and time derivatives of temperature (upper) at different depths. Five temperature spikes marked by A, B, C, $\mathrm{D}$, and $\mathrm{E}$ on $200 \mathrm{~m}$ figure coincide with the date of typhoons making landfall in Taiwan (the typhoon names are listed in Table 1. The temperature signals have been magnified in Fig. 7). The temperature spikes were also found in most others figures. The numbers from 1 to 17 in each figure show earthquakes that occurred near Kueishantao. 

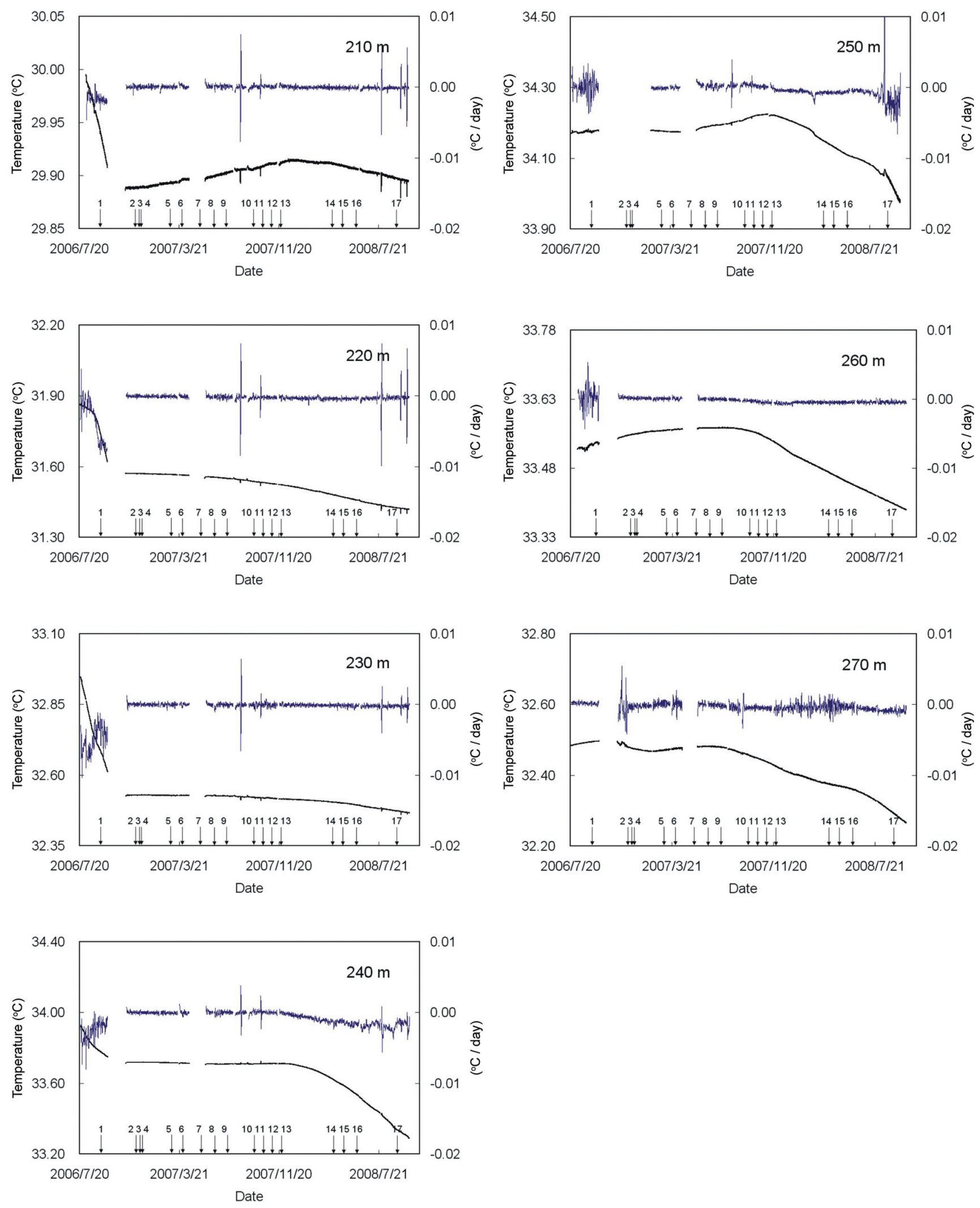

Fig. 5. (Continued) 
Table 1. Conductivity, heat capacity, and diffusivity of core samples at different depths. To reduce the measurement error, two or three samples were analyzed around the same depth.

\begin{tabular}{|c|c|c|c|c|}
\hline $\begin{array}{l}\text { depth } \\
\text { (m) }\end{array}$ & $\begin{array}{c}\text { sample } \\
\text { no. }\end{array}$ & $\begin{array}{c}\text { conductivity } \\
{\left[\mathbf{W}(\mathbf{m ~ k})^{-1}\right]}\end{array}$ & $\begin{array}{c}\text { heat capacity } \\
\times 10^{6}\left[\mathrm{~J}(\mathrm{~kg} \mathrm{k})^{-1}\right]\end{array}$ & $\begin{array}{c}\text { diffusivity } \\
\times 10^{-6}\left[\mathrm{~m}^{2} \mathrm{~s}^{-1}\right]\end{array}$ \\
\hline \multirow[t]{4}{*}{54} & 1 & 1.62 & 1.75 & 0.93 \\
\hline & 2 & 1.47 & 1.93 & 0.76 \\
\hline & 3 & 1.42 & 1.72 & 0.83 \\
\hline & average & 1.50 & 1.80 & 0.84 \\
\hline \multirow[t]{3}{*}{136} & 1 & 1.29 & 1.78 & 0.72 \\
\hline & 2 & 1.28 & 1.79 & 0.72 \\
\hline & average & 1.29 & 1.79 & 0.72 \\
\hline \multirow[t]{3}{*}{199} & 1 & 1.49 & 1.81 & 0.82 \\
\hline & 2 & 1.43 & 1.89 & 0.76 \\
\hline & average & 1.46 & 1.85 & 0.79 \\
\hline \multirow[t]{4}{*}{270} & 1 & 2.2 & 2.02 & 1.09 \\
\hline & 2 & 2.13 & 1.91 & 1.11 \\
\hline & 3 & 2.16 & 2.04 & 1.06 \\
\hline & average & 2.16 & 1.99 & 1.09 \\
\hline
\end{tabular}

heat pulses have not been found in other monitoring wells on land, we initially hypothesized that strong ocean waves and storms which impact Kueishantao island may be factors which disturb the groundwater level. The magnitudes of the heat pulses were between -0.023 and $0.015^{\circ} \mathrm{C}$; therefore, the change in water level was estimated to be between -23 and $15 \mathrm{~cm}$ by referring to the geotherm measurement if the heat pulses were solely affected by the groundwater. However, the magnitude of heat pulse did not seem to be related to the strength of the typhoon. During the typhoon season, the high rainfall (Fig. 7) raises groundwater levels and increases the hydrostatic pressure at the depths of temperature measurements. Without further investigation, it is difficult to propose a mechanism to explain why positive and negative heat pulses can occur simultaneously.

\subsection{Earthquake}

During earthquakes, hot water in the vicinity of magma could flow up to the surface along fractures and cause an increase in the temperature of geothermal wells (Silver and Valette-Silver 1987). To explain the possibility of temperature variation induced by crustal movement, we examined earthquakes that occurred from June 2006 to October 2008.

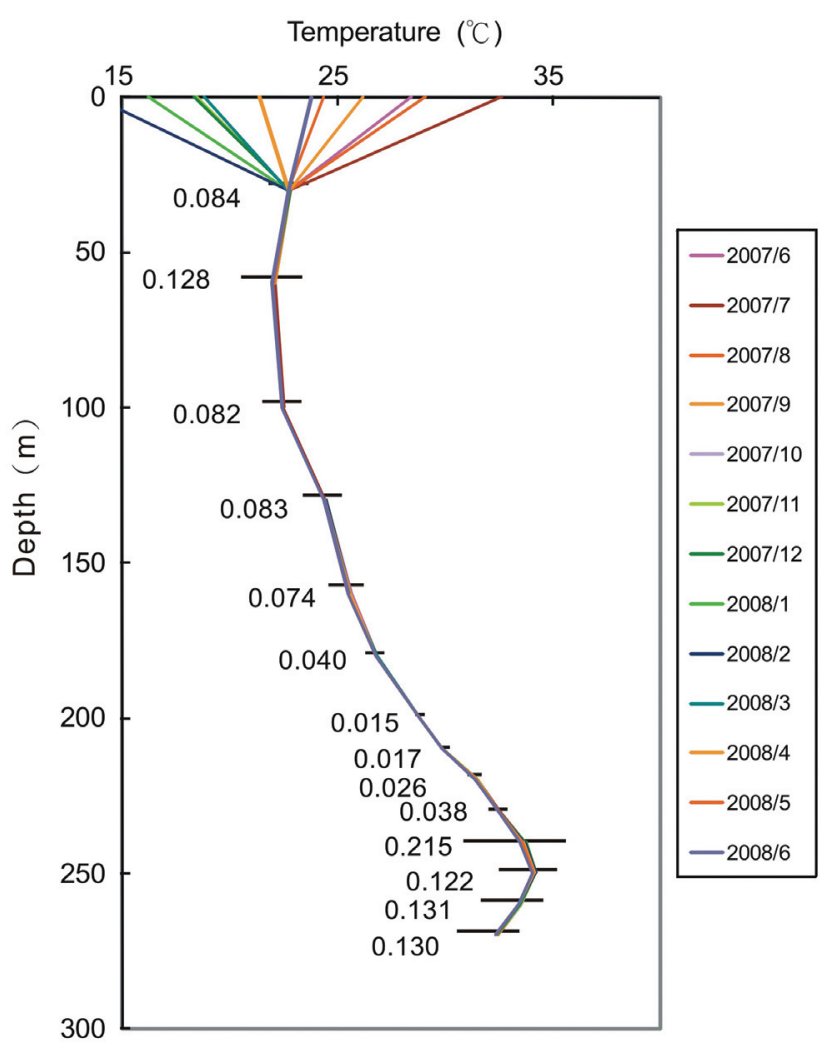

Fig. 6. The vertical temperature profile. The numbers at different depths are the annual fluctuation which is expressed as the length of the horizontal bar. Except for the surface one, the highest annual fluctuation is at $240 \mathrm{~m}$ depth.

Seventeen earthquakes in magnitude of 3.4 to 5.1 were selected within a $50 \mathrm{~km}$ radius of the Kueishantao center. The earthquakes are indicated in Fig. 5 and the locations of the earthquakes are shown in Fig. 8.

At depths between 180 and $270 \mathrm{~m}$, the temperature increased gradually after earthquake number 1 occurred on 14 September 2006 and decreased after the earthquake number 13 occurred on 29 November 2007 (Fig. 5). Because the main Neutou fault crosses in the south offshore Kueishantao island, we expected that fluid flow along the fault may be changed by the earthquakes. In that event, the temporal variation of temperature in the well may be detected. However, the locations of other earthquakes are too random to explain well the relationship between temperature variation and the occurrence of the earthquakes. The magnitude and the depth of the earthquakes can not reasonably depict the related temperature variation either. The daily temperature change rate $\left({ }^{\circ} \mathrm{C}\right.$ day $\left.{ }^{-1}\right)$ was estimated to be between 0.0003 and $-0.0010^{\circ} \mathrm{C}$ below $30 \mathrm{~m}$ depth (Fig. 5). No anomaly of the daily change rate was observed at the time the earthquakes occurred. These earthquakes maybe not large enough to cause a significant change of fluid flow in the 270-m subsurface section; however, more temperature observation data are needed to compare. 


\section{CONCLUSION}

Temperatures between 21 and $34^{\circ} \mathrm{C}$ were recorded by 15 high resolution temperature loggers at different depths in a 290-m borehole. In our 2-year continuous monitoring dataset, no daily or seasonal periodicity was found except at the surface. A heat conduction equation on half space was applied to predict the depth of the surface temperature influ- ence. The result showed that the component from surface temperature variation was negligible below $30 \mathrm{~m}$ depth. Temperatures declined at a rate of $0.048-0.116^{\circ} \mathrm{C} \mathrm{yr}^{-1}$ at most depths. Three main geotherms were identified. The geotherms were $-0.6,9.7$, and $-8.5^{\circ} \mathrm{C}(100 \mathrm{~m})^{-1}$ at depths of $30 \sim 110,110 \sim 250$, and below $250 \mathrm{~m}$, respectively. The shallowest one is mainly affected by groundwater convection. The middle high geotherm is similar to that found
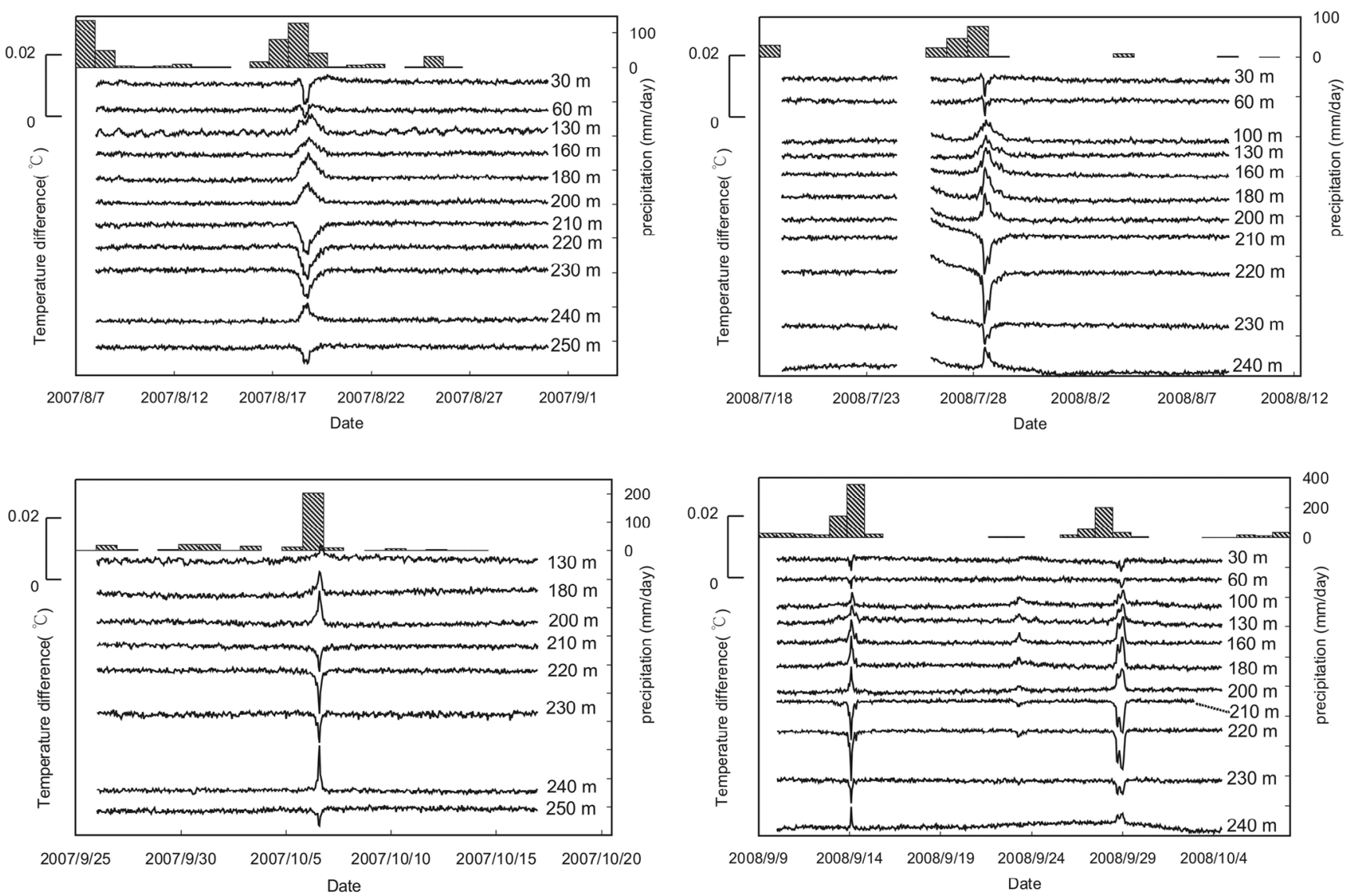

Fig. 7. Five heat pulses and the rainfall observed during the monitoring period. The events were exactly on the day when a typhoon made landfall in Taiwan. The positive/negative pulses may be caused by the change in groundwater level which is usually consistent with rainfall or may be caused by local earthquakes induced by a landslide due to the storm.

Table 2. Five heat pulses during the period. They occurred on the day when a typhoon attacked Taiwan. The velocity is the maximum of wind reported from the Central Weather Bureau.

\begin{tabular}{lccccc}
\hline & $\mathbf{1}$ & $\mathbf{2}$ & $\mathbf{3}$ & $\mathbf{4}$ & $\mathbf{5}$ \\
\hline Date & $2007 / 8 / 18$ & $2007 / 10 / 6$ & $2008 / 7 / 29$ & $2008 / 9 / 14$ & 21 \\
Duration $(\mathrm{hr})$ & 32 & 15 & 16 & $-0.022 \sim 0.014$ & $-0.018 \sim 0.013$ \\
Amplitude $\left({ }^{\circ} \mathrm{C}\right)$ & $-0.014 \sim 0.011$ & $-0.014 \sim 0.015$ & $-0.023 \sim 0.014$ & Sinlaku & Jangmi \\
Typhoon & Sepat & Krosa & 51 & 51 & 53 \\
Velocity $\left(\mathrm{m} \mathrm{s}^{-1}\right)$ & 53 & 53 -Wong & 53 \\
\hline
\end{tabular}




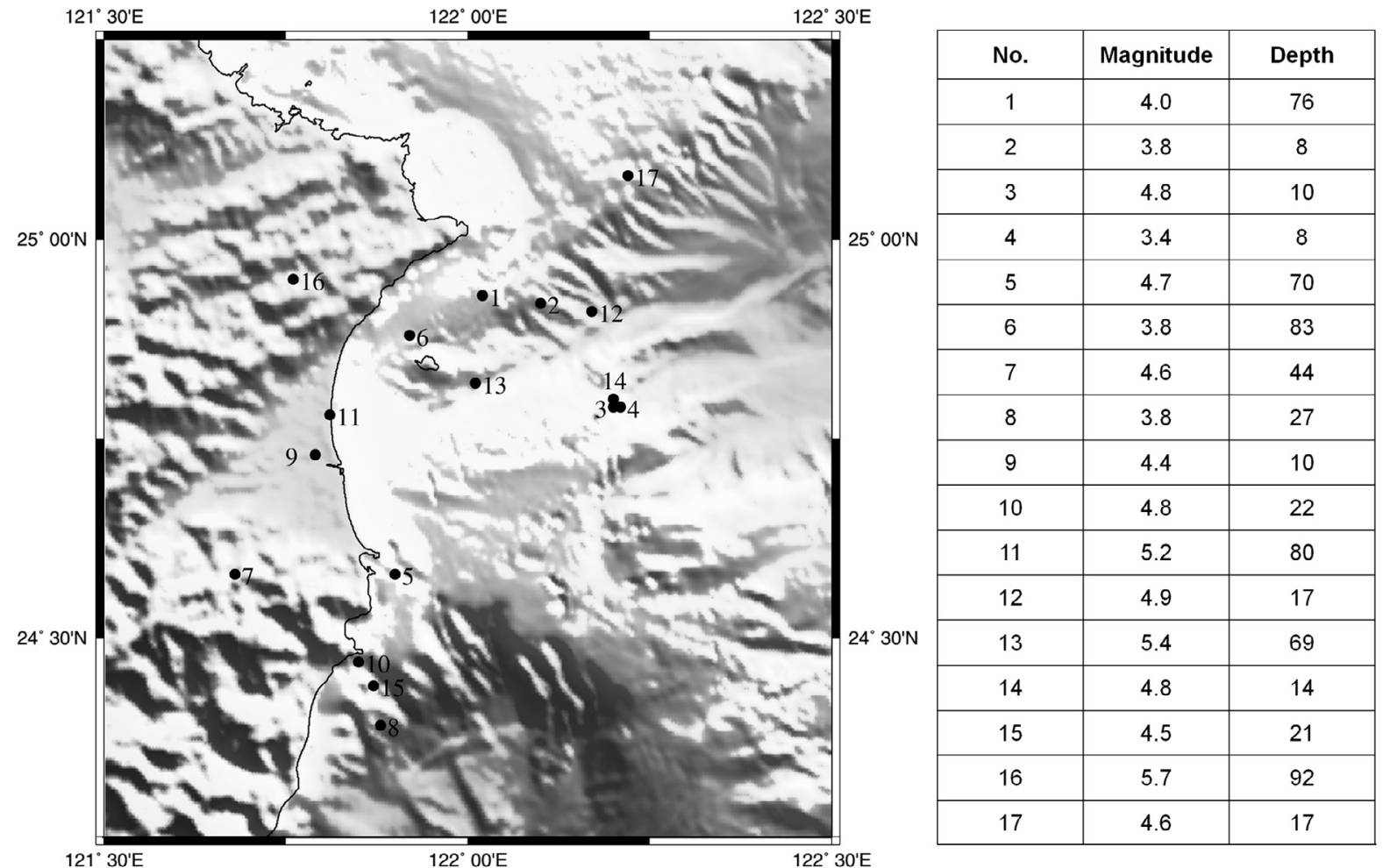

Fig. 8. The locations of the 17 earthquakes within a $50 \mathrm{~km}$ radius from Kueishantao center. The magnitude and depth of each earthquake are listed at the bottom.

offshore, south of Kueishantao. Heat flow was estimated to be about $153 \mathrm{~mW} \mathrm{~m}^{-2}$. We believe the high geotherm and heat flow may be a common phenomenon in the Kueishantao volcano area. The bottom section with an extreme low negative geotherm is probably affected by groundwater that migrated from the fracture zones near the hole bottom.

Five heat pulses were detected each summer. The dates of heat pulses coincide with those days when typhoons made landfall in Taiwan. Our data suggest that spike heat pulses, lasting for dozens of hours, are caused by the influence of typhoons, though the mechanism remains uncertain. Earthquakes located $50 \mathrm{~km}$ in radius of Kueishantao center did not seem to have a clear relationship of their occurrence to temperature variation in the borehole. It might be that these earthquakes were not large enough to see the effect. The evidence from this study shows that further observations on borehole temperatures and factors related to the variations are greatly needed.

Acknowledgements The authors would like to thank Mr. L. Kubik for critical review of the earlier version of the manuscript. We acknowledge the efforts of C. D. Tsai, S. $\mathrm{H}$. Lee, and K. C. Liao in the maintenance of the equipment and the data acquisition. This research was supported by the Central Geological Survey of the Ministry of Economic Affairs, Taiwan.

\section{REFERENCES}

Carslaw, H. A. and J. C. Jaeger, 1959: Conduction of Heat in Solid, $2^{\text {nd }}$ Ed., Oxford University Press.

Chen, C. H., 1990: Igneous Rocks in Taiwan. Cent. Geol. Surv., MOEA, Taiwan, ROC, 137 pp. (in Chinese)

Chen, C. T. A., Z. Zeng, F. W. Kuo, T. F. Yang, B. J. Wang, and Y. Y. Tu, 2005: Tide-influenced acidic hydrothermal system offshore NE Taiwan. Chem. Geol., 224, 69-81, doi: 10.1016/j.chemgeo.2005.07.022. [Link]

Chen, Y. G., W. S. Wu, C. H. Chen, and T. K. Liu, 2001: A date for volcanic eruption inferred from a siltstone xenolith. Quat. Sci. Rev., 20, 869-873, doi: 10.1016/S0 277-3791(00)00047-0. [Link]

Chiang, H. T., C. T. Shyu, H. Y. Chang, and Y. C. Chen, 2005: The preliminary study of the monitoring geothermal variation in Tatun volcano area. Annual Meeting of Geological Society, Taipei, 123 pp. (in Chinese)

Chiang, H. T., C. T. Shyu, and H. Y. Chang, 2008a: The geothermal signal in Kueishantao island offshore northeastern Taiwan. Annual Meeting of Chinese Geology Association, Tainan, Taiwan. (in Chinese)

Chiang, H. T., C. T. Shyu, and H. Y. Chang, 2008b: The study of shallow geothermal water in Ilan plain, northeastern Taiwan. Min. Metall., 52, 112-121. (in Chinese)

Harris, R. N. and D. S. Chapman, 1997: Borehole tempera- 
tures and a baseline for $20^{\text {th }}$-century global warming estimates. Science, 275, 1618-1621, doi: 10.1126/scien ce.275.5306.1618. [Link]

Hsu, L. C., 1963: Petrology of the Pleistocene andesite from Kueishantao, Northern Taiwan. Acta Geol. Taiwan., 10, 29-40.

Huang, S. P., H. N. Pollack, and P. Y. Shen, 2008: A late Quaternary climate reconstruction based on borehole heat flux data, borehole temperature data, and the instrumental record. Geophys. Res. Lett., 35, L13703, doi: 10.1029/2008GL034187. [Link]

Igarashi, G., T. Fujii, T. Mori, K. Notsu, and S. Watanabe, 2000: Continuous monitoring of fumarolic gas flux at a bore hole in an active volcanic island. Geophys. Res. Lett., 27, 1539-1542, doi: 10.1029/1999GL008450. [Link]

Juang, W. S. and J. C. Chen, 1989: Geochronology and geochemistry of volcanic rocks in northern Taiwan. Bull. Cent. Geol. Surv., 5, 31-66. (in Chinese)

Lee, S. C., G. Shor, L. D. Jr. Bibee, R. S. Lu, and T. W. C. Hilde, 1980: Okinawa Trough: Origin of a back-arc basin. Mar. Geol., 35, 219-241.

Letouzey, J. and M. Kimura, 1986: The Okinawa Trough: Genesis of a back-arc basin developing along a continental margin. Tectonophysics. 125, 209-230, doi: 10.10 16/0040-1951(86)90015-6. [Link]

Lin, C. H., L. W. Hsu, M. Y. Ho, T. C. Shin, K. J. Chen, and Y. H. Yeh, 2007: Low-frequency submarine volcanic swarms at the southwestern end of the Okinawa Trough. Geophys. Res. Lett., 34, L06310, doi: 10.1029/ 2006GL029207. [Link]

Lin, G. W., H. Chen, Y. H. Chen, and M. J. Horng, 2008: Influence of typhoons and earthquakes on rainfall-induced landslides and suspended sediments discharge. Eng. Geol., 97, 32-41, doi: 10.1016/j.enggeo.2007.12.001. [Link]

Lin, J. Y., S. K. Hsu, and J. C. Sibuet, 2004: Melting features along the western Ryukyu slab edge (northeast
Taiwan): Tomographic evidence. J. Geophys. Res., 109, B12402, doi: 10.1029/2004JB003260. [Link]

Lou, C. P., 2001: The study of the volcano distribution and the structure of south Okinawa Trough. Masters Thesis, National Taiwan University, Taipei, Taiwan, ROC, 67 pp. (in Chinese)

Shyu, C. T. and C. S. Liou, 2001: Heat flow of the southwestern end of the Okinawa Trough. Terr. Atmos. Ocean. Sci., 12 (Suppl. Issue), 305-317.

Sibuet, J. C., B. Deffontaines, S. K. Hsu, N. Thareau, J. P. Le Formal, C. S. Liu, and the ACT Party, 1998: Okinawa Trough backarc basin: Early tectonic and magmatic evolution. J. Geophys. Res., 103, 30245-30267, doi: 10.1029/98JB01823. [Link]

Silver, P. G. and J. N. Valette-Silver, 1987: A spreading episode at the southern end of the San Andreas fault system. Nature, 326, 589-593, doi: 10.1038/326589a0. [Link]

Sudo, Y. and A. W. Hurst, 1998: Temperature changes at depths to 150 metres near the active crater of Aso Volcano: Preliminary analysis of seasonal and volcanic effects. J. Volcanol. Geotherm. Res., 81, 159-172, doi: 10.1016/S0377-0273(98)00003-1. [Link]

Tilling, R. I., 1989: Volcanic hazards: Short course in geology. Vol. 1, 28 ${ }^{\text {th }}$ International Geological Congress, Washington, DC, $123 \mathrm{pp}$.

Wu, Q. and T. Zhan, 2008: Recent permafrost warming on the Qinghai-Tibetan Plateau. J. Geophys. Res., 113, D13108, doi: 10.1029/2007JD009539. [Link]

Yang, T. F., T. F. Lan, H. F. Lee, C. C. Fu, P. C. Chuang, C. H. Lo, C. H. Chen, C. T. A. Chen, and C. S. Lee, 2005: Gas compositions and helium isotopic ratios of fluid samples around Kueishantao, NE offshore Taiwan and its tectonic implications. Geochem. J., 39, 469-480.

Zeni, L., A. Minardo, Z. Petrillo, M. Piochi, R. Scarpa, and R. Bernini, 2007: Distributed optical fiber sensors: An approach for monitoring the thermal gradient at the Campi Flegrei caldera. Geophy. Res. Abs., 9, 04074. 